\title{
Organic Geochemical Evaluation of Shale Units of Bokh Formation, Ogaden Basin, Ethiopia
}

\author{
Temesgen Oljira ${ }^{1 *}$, Matthew E. Nton ${ }^{2}$, Oluwadayo 0. Sonibare ${ }^{3}$ \\ ${ }^{1}$ Pan African University Institute of Life and Earth Science (Including Health and Agriculture), University of Ibadan, Ibadan, \\ Nigeria \\ ${ }^{2}$ Department of Geology, University of Ibadan, Ibadan, Nigeria \\ ${ }^{3}$ Department of Chemistry, University of Ibadan, Ibadan, Nigeria \\ Email: ^temesgenoli@gmail.com
}

How to cite this paper: Oljira, T., Nton, M.E. and Sonibare, O.O. (2020) Organic Geochemical Evaluation of Shale Units of Bokh Formation, Ogaden Basin, Ethiopia. Open Journal of Geology, 10, 565-578. https://doi.org/10.4236/ojg.2020.105025

Received: November 21, 2019

Accepted: May 26, 2020

Published: May 29, 2020

Copyright $\odot 2020$ by author(s) and Scientific Research Publishing Inc. This work is licensed under the Creative Commons Attribution International License (CC BY 4.0).

http://creativecommons.org/licenses/by/4.0/

\begin{abstract}
Shale sample from Bokh Formation, Ogaden basin, Ethiopia was assessed for their petroleum potential by Rock-Eval pyrolysis. The Total Organic Carbon (TOC) values range from 0.76 to $0.86 \mathrm{wt} \%$. These values exceed the minimum value of $0.5 \mathrm{wt} \%$ required for potential petroleum source rocks. The genetic potential (GP) and hydrogen index (HI) values range from 0.09 to $0.5 \mathrm{mg} / \mathrm{g}$ and $8-32 \mathrm{mgHC} / \mathrm{gTOC}$, respectively. These values are generally lower than the minimal $2 \mathrm{mg} / \mathrm{g} \mathrm{GP}$ and $200 \mathrm{mgHC} / \mathrm{g} \mathrm{HI}$ required for a potential source rock. Several plots from the Rock-Eval pyrolysis data classify the samples as type IV kerogen with no potential to generate hydrocarbons. The Tmax and Production Index (PI) values range from $388^{\circ} \mathrm{C}$ to $453^{\circ} \mathrm{C}$ and 0.28 to 0.46 , respectively. These values indicate that the shales are thermally matured. These results show that the shales from the Bokh Formation in Ogaden basin have no potential to generate hydrocarbons mainly crude oil, but are thermally matured and may generate natural gas.
\end{abstract}

\section{Keywords}

Ogaden Basin, Bokh Formation, Shale, Hydrocarbon, Source Rock

\section{Introduction}

The sedimentary regions of Ethiopia cover a large portion of the country and comprise five distinct sedimentary basins namely; the Ogaden, Abay (Blue Nile), Mekele, Gambela and Southern Rift Basins [1] [2] [3] [4]. The development of most of these basins is related to the extensional tectonic events that had taken place intermittently since the Late Paleozoic and continued up to Tertiary [1] 
[5]. The Ogaden, Abay and Mekele basins are presumed to be intracontinental rift basins formed as a result of extensional stresses induced by the break-up of Gondwanaland in Upper Paleozoic [5].

The search for commercial hydrocarbon deposits (oil/gas) in the Ogaden basin has remained a real concern especially to oil companies and many researchers. Previous exploration activities in search for economically viable hydrocarbon reservoirs were focused on the regional geology [5] [6] [7] [8] basin evolution as well as biostratigraphy [2] [9] of the basin with little information about the hydrocarbon potential [2] [9] and thermal maturity [2]. This study therefore examines the associated shales in Bokh Formation within the Ogaden basin in order to determine the hydrocarbon generative potential of the shales in the basin. Such study will be good to increase value to exploration and researches.

\section{Geological Setting of Ogaden Basin}

The Ogaden basin is bounded to the north and northwest by the Ethiopian portion of the Miocene-Quaternary East African Rift, and to the west and southwest by basement complex [5] and to the south, east and northeast (Figure 1). In Ethiopian, Ogaden Basin adjoins a sedimentary basin in Somalia, which developed in the same regional context [1] [3] [4]. The Ogaden basin has a total sediment thickness of $10,000 \mathrm{~m}$ and presents an economically viable hydrocarbon deposit [2].

The Ogaden basin is said to have a maximum sediment thickness (at deeper parts) of $7 \mathrm{~km}$ at the central and southwestern part of the sub-basin around Bodle deep with an aerial extent of about $75,000 \mathrm{~km}^{2}$ [10]. The development of

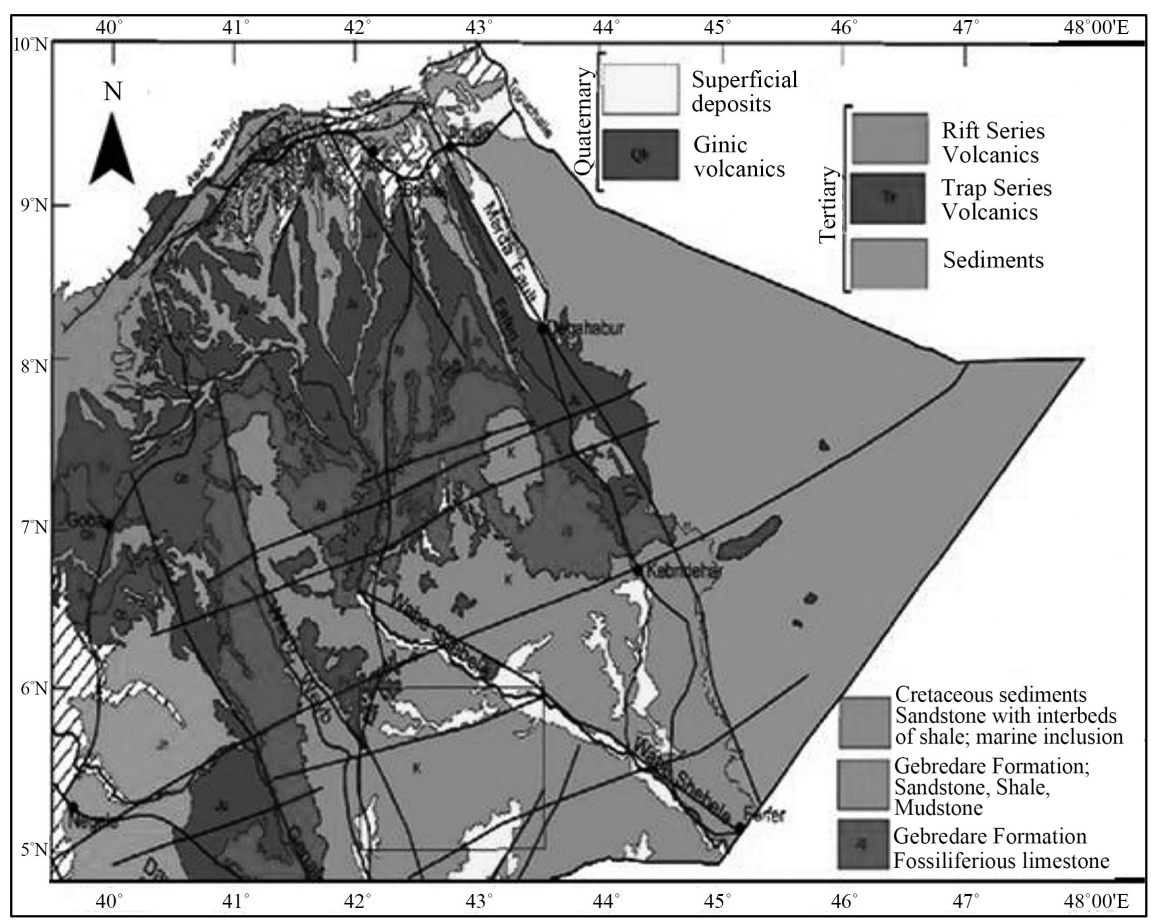

Figure 1. Geological map of Ogaden Basin, Ethiopia [13]. 
the Ogaden Basin is related to the break-up of Gondwanaland [5] [6]. The source of the sedimentary fill is mainly the Tethys sea during the Mesozoic times, the cross-river channels, and lacustrine depositional environments [5] [8] [10] [11] [12].

From Permian to Jurassic times, a tri-radial system of north-south, NE-SW and NW-SE trending grabens developed as a consequence of the opening of the North Atlantic and Proto-Indian Oceans [5] [14]. In Ogaden basin, sediments deposited are associated with different phases of deformation i.e. the pre-rift sediments (Calub Formation), initial rift sediment (Bokha and Gumburo Formation), early rift sediment (Adigrat sandstone Formation and Lower Hamanlei Formation), Syn-rift sediments (Middle Hamanlei) and post-rift sediments (Antalo Limestone and Ambaradam Formation) (Figure 2). The stratigraphy of Ogaden basin from oldest to youngest is Calub Formation, Bokha Formation, Gumburo Formation, Adigrat sandstone Formation, Hamanlei Formation, Uarandab Formation, Gabredarre Formation, Antalo limestone Formation and Ambaradam Formation [2] [6] [7].

Geologically, Ogaden basin comprised non-marine to deep marine clastics, very thick, shallow to deep marine carbonates (in complex association with argillaceous clastics) and evaporites. Ogaden basin is characterized by enormous lithologic heterogeneity in both lateral and vertical extensions derived from a range of paleoenvironmental settings ranging from late Paleozoic to Mesozoic [2] [5] [9] deduced the depositional environment of the basin as it ranges from continental alluvial fan, fluviatile and deltaic clastics to lacustrine argillaceous types palynological analysis. Later [2] calculated time-temperature indices of rock maturation using Lopatin Model and suggested the presence of favorable environments for generation of petroleum, especially gas, in the Paleozoic and Mesozoic rocks of the Ogaden Basin. On this note, he suggested that the Bokha Shale and the Hamanlei Formation could be potential hydrocarbon source rocks. [5] suggested that the potential source within the Ogaden basin could be the organic-rich Bokh Shale, transition zone and Urandab Shales with fair to good petroleum potential up to $20 \mathrm{~kg} \mathrm{HC/ton} \mathrm{rock.} \mathrm{[5]} \mathrm{reported} \mathrm{that} \mathrm{sandstones} \mathrm{facies} \mathrm{of}$ the Calub formation and Adigrat Sandstone Formations as well as the carbonate's facies in the Hamanlei Formation can serve as reservoir. There are also both structural and stratigraphic traps in the basin as reported by [5].

\section{Material and Method}

\subsection{Sample Collections}

The samples were obtained from the Ministry of Mines, Petroleum and Natural Gas of Ethiopia (MoMPNG), Addis Ababa. Fifteen core samples were collected from shale unit of Bokh Formation from Calub-2 and Calub-3 wells at depths ranging from 3280 to $3595 \mathrm{~m}$ and 3320 to $3585 \mathrm{~m}$, respectively. The samples were subjected to detailed lithologic description as discussed in Figure 3 and Figure 4. 


\subsection{Determination of Total Organic Carbon}

The total organic carbons (TOC) contents of the shales were determined following acid treatment with $10 \% \mathrm{HCl}$ for $24 \mathrm{hrs}$ to remove carbonate. The carbonate -free samples were thoroughly rinsed with distilled water to remove acid residue and dried at $105^{\circ} \mathrm{C}$ for $4 \mathrm{hrs}$. The samples were then combusted in LECO carbon analyzer available at ALS Oil and Gas Laboratory, Houston, Texas, USA at a temperature of $1350^{\circ} \mathrm{C}$. The carbon dioxide generated by the combustion of organic materials in the sample is quantitatively measured using an infrared detector. This quantitative measurement is reported as the percentage (by weight) of total organic carbon.

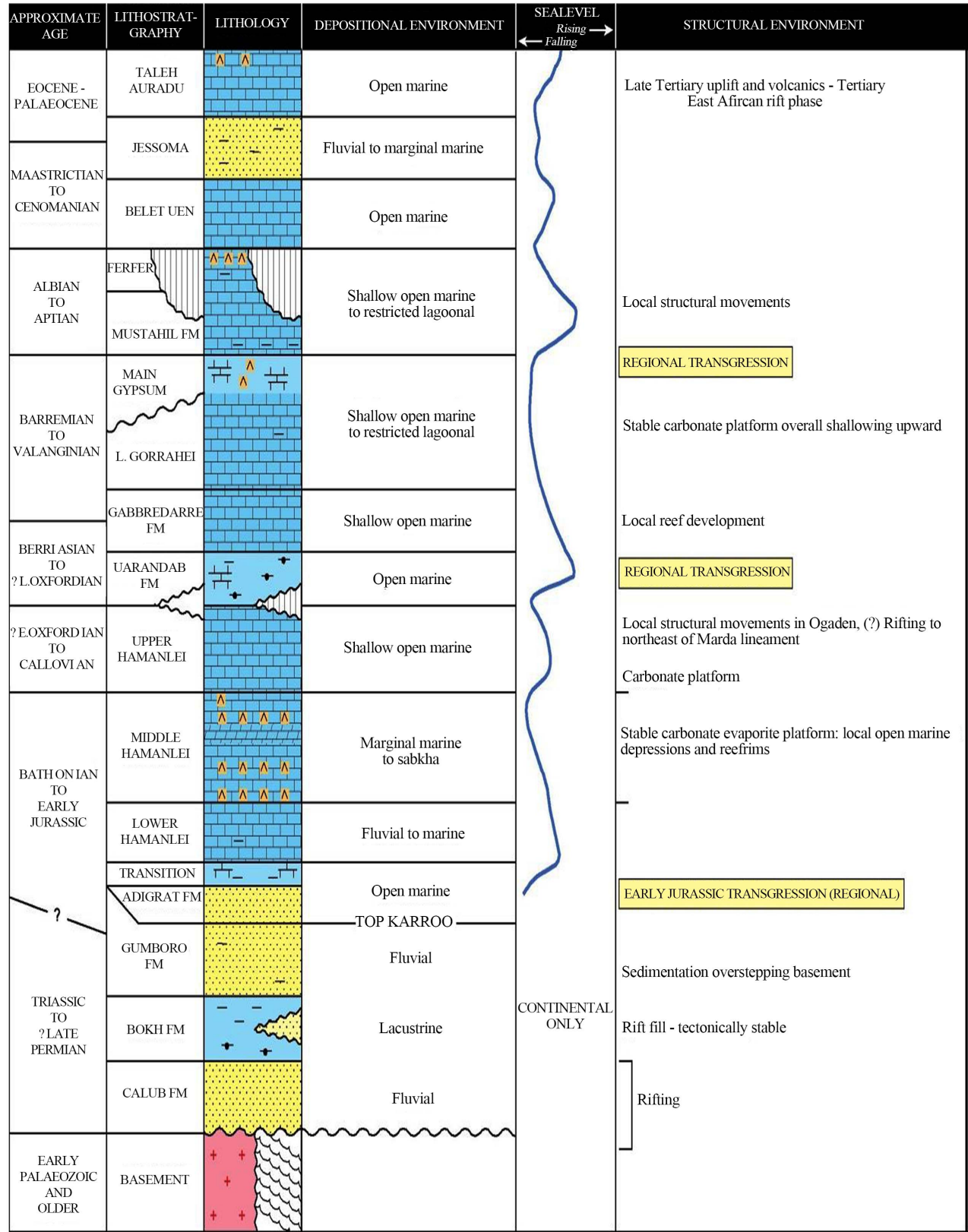

Figure 2. Stratigraphy and petroleum system of the Ogaden Basin [2]. 


\subsection{Rock Eval Pyrolysis}

Rock-Eval analyses were performed using Rock-Eval 6 analyzer. $100 \mathrm{mg}$ of powdered rock sample was progressively heated to $850^{\circ} \mathrm{C}$ using a special temperature program. Four characteristic peaks were obtained during the heating. $\mathrm{S} 1$ which is the first peak represents hydrocarbon already present in the sample which are mainly stripped at temperatures about $300^{\circ} \mathrm{C}$. The second peak, S2 represents hydrocarbons generated through thermal cracking of kerogen at temperatures between $300^{\circ} \mathrm{C}$ and $650^{\circ} \mathrm{C}$, while $\mathrm{S} 3$ peak represents the $\mathrm{CO}_{2}$ which is generated from the kerogen at the same time the $\mathrm{S} 2$ hydrocarbons are being generated. The fourth peak, $\mathrm{S} 4$ indicates the amount of $\mathrm{CO}_{2}$ produced through oxidation during combustion at a temperature of about $850^{\circ} \mathrm{C}$. OPTKIN software was used for acquisition of pyrolysis kinetic parameters. The parameters include S1, S2, S3, hydrogen index (HI), oxygen index (OI), S2/S3, production index (PI), Ro\% and Tmax. Standard were run in between the analyses to ensure reproducibility and accuracy of the data generated.

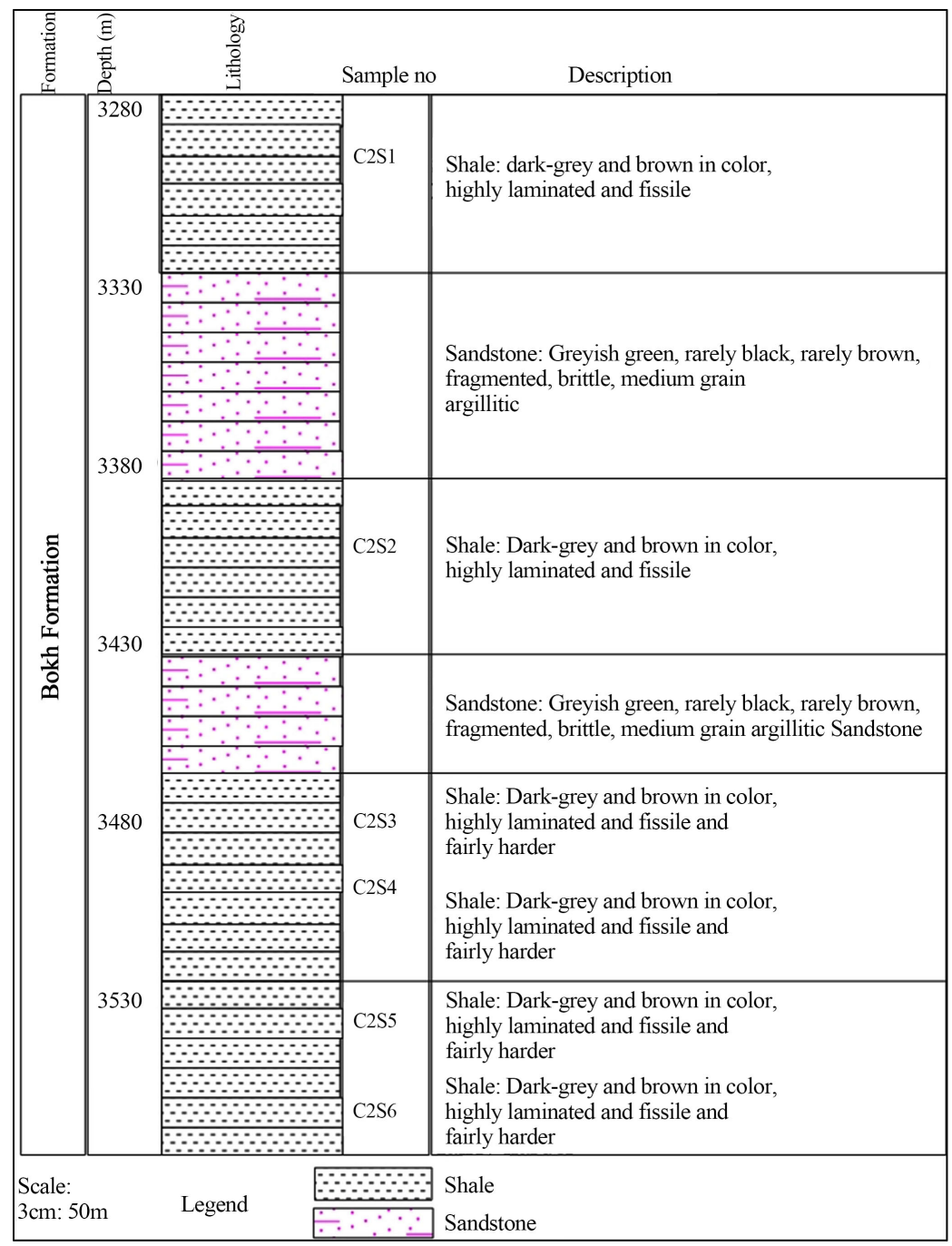

Figure 3. Litho-stratigraphic section of Bokh Formation, Calub-2 well, Ogaden basin. 


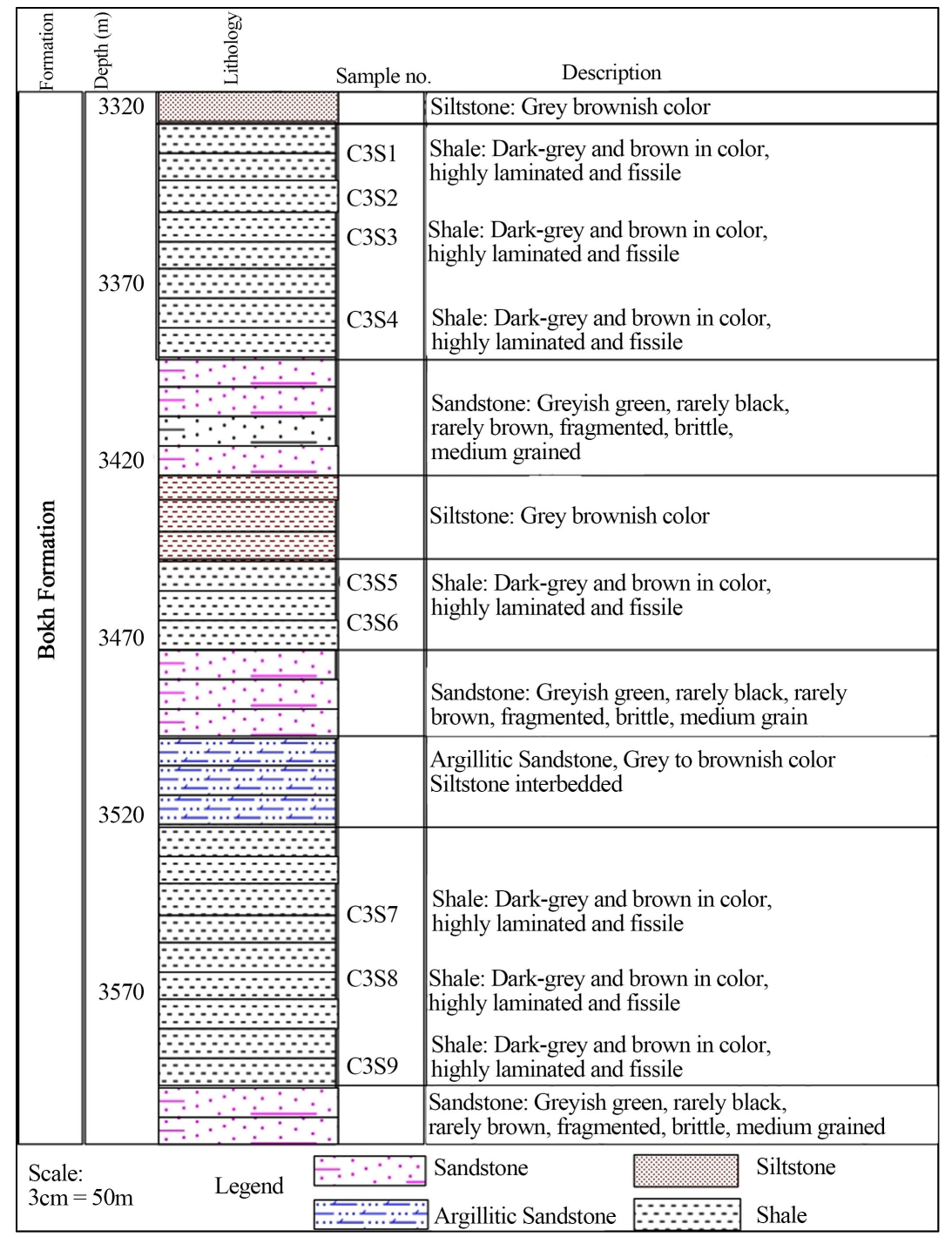

Figure 4. Litho-stratigraphic section of Bokh Formation, Calub-3 well, Ogaden basin.

\subsection{Data Presentation}

The results obtained from TOC and Rock Eval pyrolysis were presented in tables using Microsoft Excel (Table $1 \&$ Table 2). Then the results were interpreted using PetroMod1DTM Express (version 1.1) of Integrated Exploration Systems GmbH (IES), Germany.

\section{Result and Discussion}

\subsection{Result}

\subsubsection{Lithology}

The lithologic sections of the Bokh formation reveal alternating sequences of shale, siltstone, argillite and argillitic sandstone (Figure 3 and Figure 4). The shale units are dark-grey and brown in color, highly laminated and fissile. The Siltstone units are grey brownish color rock. Argillite is another unit within the Bokh Formation. It is known by its greyish green, rarely black, rarely brown, 
fragmentary, brittle, medium hard. It is occasionally grading to siltstone, micaceous. It is distinguished by its poor lithification. Sandstone units are fine to coarse grained, poorly sorted, moderately cemented and friable. It is white to light grey with greenish tint color.

\subsubsection{TOC and Rock-Eval Pyrolysis}

The evaluation of hydrocarbon source rock is based on several geochemical parameters including Total Organic Carbon (TOC) and Rock-Eval pyrolysis to quantify the organic matter richness, hydrocarbon generating potential, thermal maturation of the organic matter and the type and origin of organic matter present in sedimentary rocks [15] [16] [17] [18] [19].

Table 1 presents the result of the evolution of the TOC contents of the Calub 2 and Calub 3 well Bokh shale unit from 3295 to $3560 \mathrm{~m}$ and 3338 to 3585 respectively. Majority of the analyzed samples TOC content is below $0.5 \mathrm{wt} \%$ (most of Calub 3 well except two samples C3-S1 and C3-S3 samples with TOC values of 0.68 and 0.86 respectively) i.e. it can't generate any hydrocarbon [16]. From the analyzed shale samples, it's possible to distinguish different intervals based on the TOC contents.

Table 1. Total organic carbon (TOC) analysis from Calub-2 and Calub-3 wells, Ogaden basin, Ethiopia.

\begin{tabular}{|c|c|c|}
\hline & & Total Organic Carbon \\
\hline \multirow{2}{*}{ Sample ID } & \multirow{2}{*}{ Depth (m) } & LECO TOC \\
\hline & & (wt\%) \\
\hline \multicolumn{3}{|c|}{ Calub 2 well } \\
\hline $\mathrm{C} 2-\mathrm{S} 1$ & 3295 & 0.83 \\
\hline $\mathrm{C} 2-\mathrm{S} 2$ & 3390 & 0.82 \\
\hline $\mathrm{C} 2-\mathrm{S} 3$ & 3480 & 0.87 \\
\hline $\mathrm{C} 2-\mathrm{S} 4$ & 3495 & 0.76 \\
\hline $\mathrm{C} 2-\mathrm{S} 5$ & 3535 & 0.45 \\
\hline $\mathrm{C} 2-\mathrm{S} 6$ & 3560 & 0.36 \\
\hline \multicolumn{3}{|c|}{ Calub 3 well } \\
\hline C3-S1 & 3338 & 0.68 \\
\hline C3-S2 & 3348 & 0.36 \\
\hline $\mathrm{C} 3-\mathrm{S} 3$ & 3356 & 0.86 \\
\hline $\mathrm{C} 3-\mathrm{S} 4$ & 3380 & 0.31 \\
\hline C3-S5 & 3450 & 0.33 \\
\hline $\mathrm{C} 3-\mathrm{S} 6$ & 3468 & 0.37 \\
\hline C3-S7 & 3550 & 0.46 \\
\hline C3-S8 & 3570 & 0.36 \\
\hline C3-S9 & 3585 & 0.47 \\
\hline
\end{tabular}




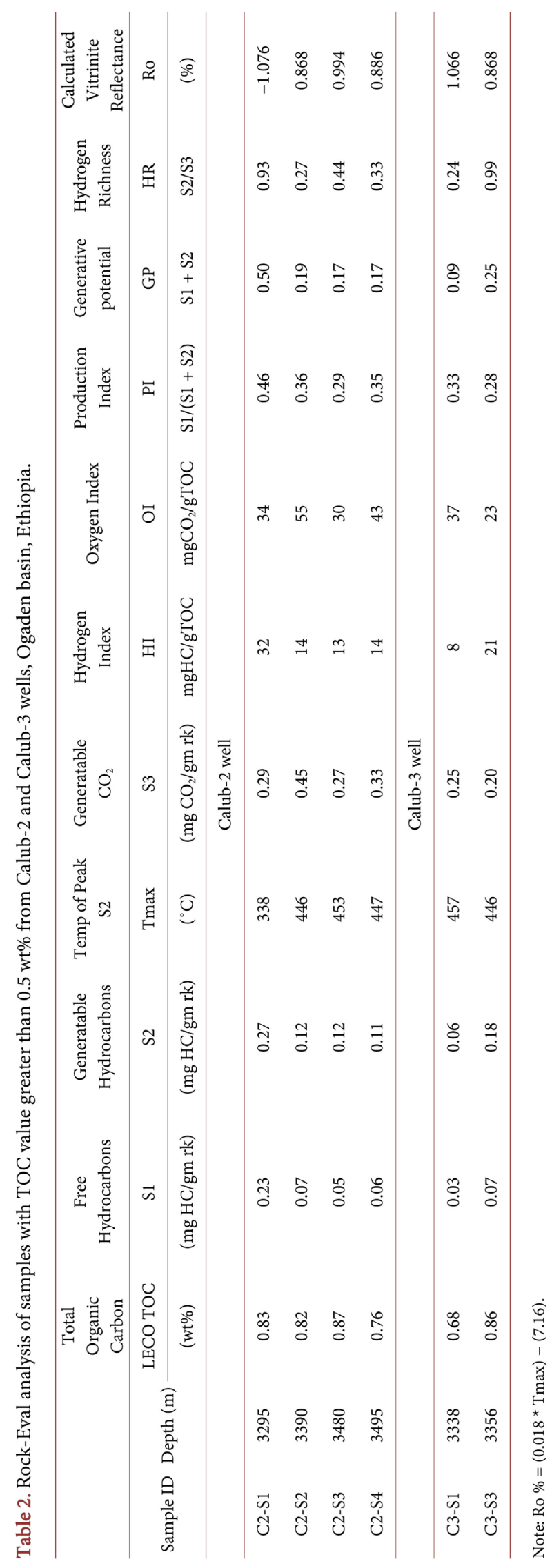




\section{1) Calub 2 well}

The evolution of the TOC contents of the Calub 2 well shale samples makes it possible to distinguish two intervals:

Interval from 3295 to $3495 \mathrm{~m}$

The TOC of shale samples in these intervals varies between 0.76 and $0.83 \mathrm{wt} \%$ with an average of $0.82 \mathrm{wt} \%$. These shales contain relatively high amounts of organic matter to be considered as potential sources of hydrocarbons.

On the other hand, these rocks are early maturing between 3295 and $3495 \mathrm{~m}$, with a Tmax ranging from $338^{\circ} \mathrm{C}$ to $453^{\circ} \mathrm{C}$. The peak of maturity is reached between 3480 and $3495 \mathrm{~m}$ with a Tmax between $447^{\circ} \mathrm{C}$ and $453^{\circ} \mathrm{C}$ (Table 2). Their hydrogen indices included are between 13 and $32 \mathrm{mg} \mathrm{HC} / \mathrm{g}$ TOC and show that the organic material is type IV, so inert (non-producing gas and oil) [16] [17] [18].

However, according to [20] these values of Tmax and hydrogen indices prove that the samples collected between 3295 to $3495 \mathrm{~m}$ are in a window of oil and condensate.

\section{Interval from 3495 to $3560 \mathrm{~m}$ :}

The TOC values of shale samples in these intervals are less important (less than $0.5 \mathrm{wt} \%$ ) and fluctuate between 0.36 and $0.46 \mathrm{wt} \%$. These values show that the interval contains an average amount of organic matter that could not be preserved in the sediments.

\section{2) Calub 3 well}

Generally, the evolution of the TOC contents of the Calub 3 well shale samples is not distinguishable into different intervals as the TOC values are less important and fluctuate between 0.31 and $0.86 \mathrm{wt} \%$ with dominant TOC values less than $0.5 \mathrm{wt} \%$. But there are two samples with TOC values of 0.68 and $0.86 \mathrm{wt} \%$ at depth of 3338 and $3356 \mathrm{~m}$ respectively with one sample showing $0.36 \mathrm{wt} \%$ between the above-mentioned depths at $3346 \mathrm{~m}$, thus, making it difficult to group into intervals.

On the other hand, the peak of maturity is reached between 3338 and $3356 \mathrm{~m}$ with a Tmax between $447^{\circ} \mathrm{C}$ and $453^{\circ} \mathrm{C}$. Their hydrogen indices included are between 8 and $21 \mathrm{mg} \mathrm{HC} / \mathrm{g}$ TOC and show that the organic material is type IV, so inert (non-producing gas and oil) [16] [17] [18].

\subsection{Discussion}

\subsubsection{Organic Matter Richness}

The TOC contents of the samples are shown in Table 1 and the Rock-Eval analysis results are shown in Table 2. The TOC contents of the shale samples range from 0.31 to $0.87 \mathrm{wt} \%$ (av. $0.59 \mathrm{wt} \%$ ). The TOC values in most of the samples are lower than $0.5 \mathrm{wt} \%$ minimal required for a potential source rock [15] [19] [21].

These values are less than that of the shales of the Bokh Formation from Hilala-1 which is about $1.27 \mathrm{wt} \%$ [22]. The plots of Total Organic Carbon values against depth (Figure 5) show that the TOC values decrease with increasing depth in both wells. 


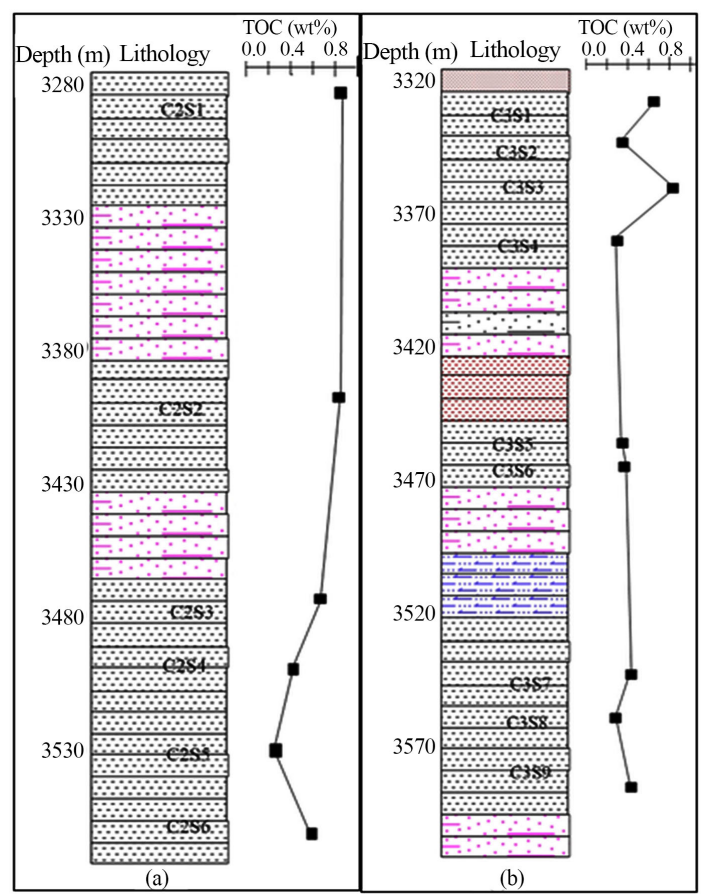

Figure 5. Plot of TOC vs. depth for Bokh shale (a) Calub-2 and (b) Calub-3 of Ogaden basin, Ethiopia.

The generation potential (GP) values of the shale's samples range from 0.17 to $0.50 \mathrm{mg} \mathrm{HC} / \mathrm{g}$ rock (av. $0.33 \mathrm{mg} \mathrm{HC} / \mathrm{g}$ rock) and 0.09 to $0.25 \mathrm{mg} \mathrm{HC} / \mathrm{g}$ rock (av. $0.17 \mathrm{mg} \mathrm{HC} / \mathrm{g}$ rock) for Calub-2 and Calub-3, respectively (Table 2). These values reveal that the organic richness of this formation is poor [19] and has no potential to generate hydrocarbons.

\subsubsection{Organic Matter Quality}

The type of organic matter contained in any particular source rock is essential for the prediction of its hydrocarbon potentials (oil or gas). The hydrogen Index (HI) values range from 13 to $32 \mathrm{mgHC} / \mathrm{gTOC}$ (av. $22.5 \mathrm{mgHC} / \mathrm{g}$ TOC) and 8 to $32 \mathrm{mgHC} / \mathrm{gTOC}$ (av. $14.5 \mathrm{mgHC} / \mathrm{gTOC}$ ) for Calub-2 and Calub-3 respectively. Generally, the HI values are lower than $200 \mathrm{mg} / \mathrm{g}$ TOC required to generate hydrocarbons. These values show that the organic matter has no potential to generate either oil or gas [16] [21]. The cross plots of TOC versus S2 [17] [18] and TOC versus HI [10] [15] [21] show that the shales are mainly type IV and inert (Figure 6 and Figure 7) with no potential to generate hydrocarbon. The cross plots of HI and OI values of the samples (Figure 8) show that the shales contained type IV kerogen which is inert [19].

\subsubsection{Thermal Maturity of the Shale}

The Tmax values of Calub-2 and Calub-3 shales range from $338^{\circ} \mathrm{C}$ to $453^{\circ} \mathrm{C}$ and $446^{\circ} \mathrm{C}$ to $457^{\circ} \mathrm{C}$ respectively. The production index (PI) for Calub-2 and Calub-3 shales range from 0.29 to 0.46 and 0.28 to 0.33 , respectively. These values exceed the minimum $435^{\circ} \mathrm{C}(\mathrm{Tmax})$ and 0.1 (PI) required for matured source rocks. Cross plots of HI against Tmax (Figure 9) show that the samples are within oil 
window and condensate-wet gas zone.

Calculated vitrinite reflectance is another parameter used to predict the thermal maturity of organic matter. The Ro of the shale within Bokh Formation ranges from $0.87 \%$ to $1.07 \%$. These values suggest early mature to peak mature status for the shale samples [21]. Cross plots of Ro vs. Tmax (Figure 10) indicate early mature (oil window) to peak mature (condensate/wet gas) for the samples.

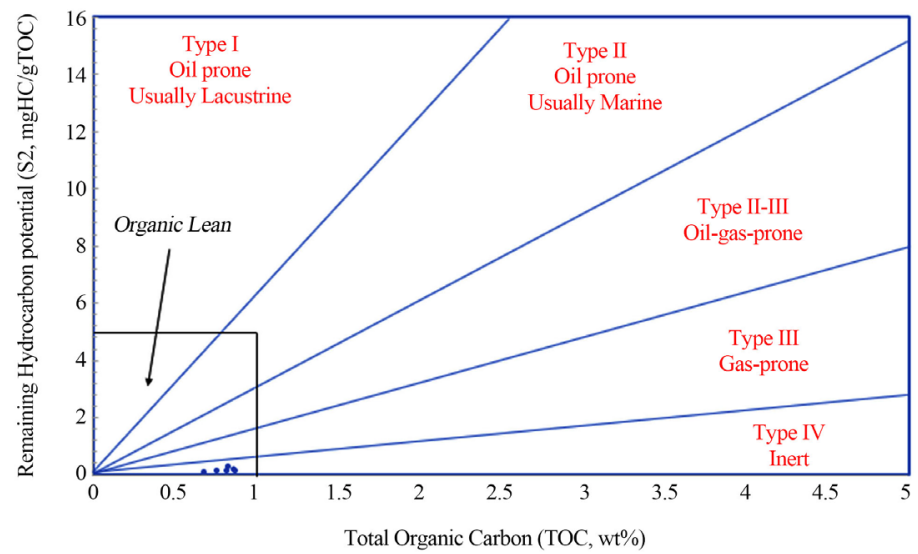

Figure 6. Plot of TOC vs. S2 for oil shales from Bokh Formation (after [17] [18]).

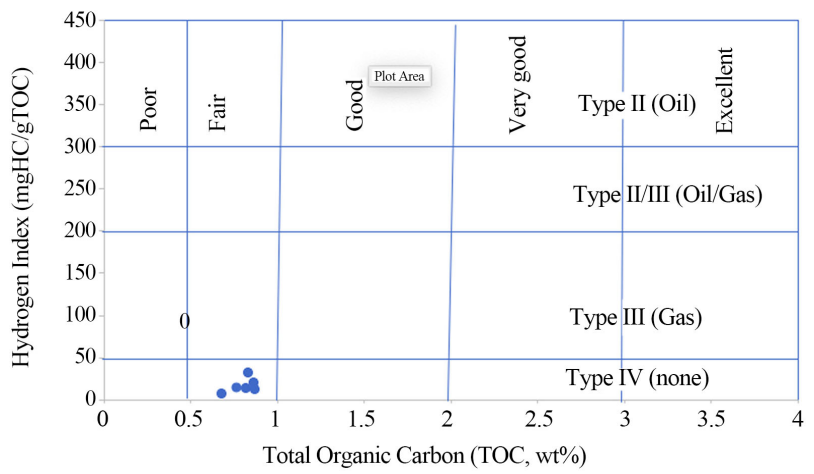

Figure 7. Plot of Hydrogen index versus TOC indicating generative potential and kerogen types.

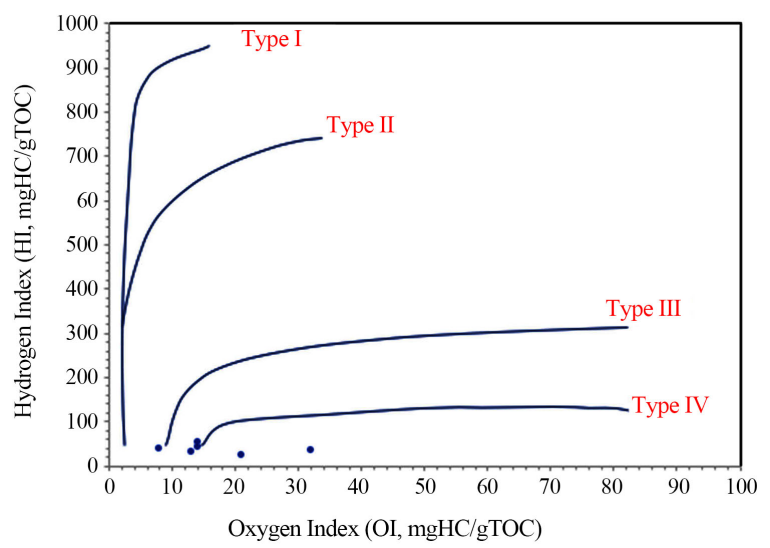

Figure 8. Plots of Oxygen index vs. Hydrogen Index (after [20]). 


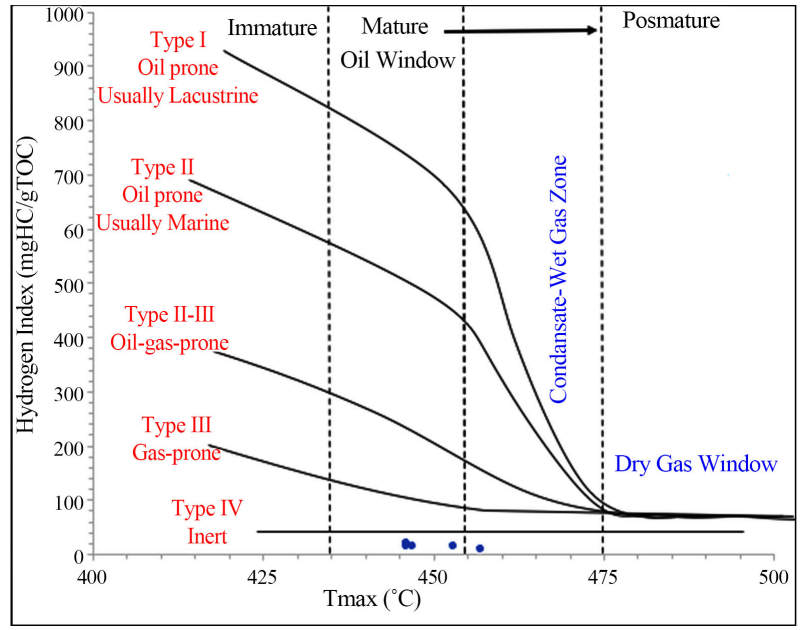

Figure 9. Plots of Tmax vs. Hydrogen index (HI) (after [20]).

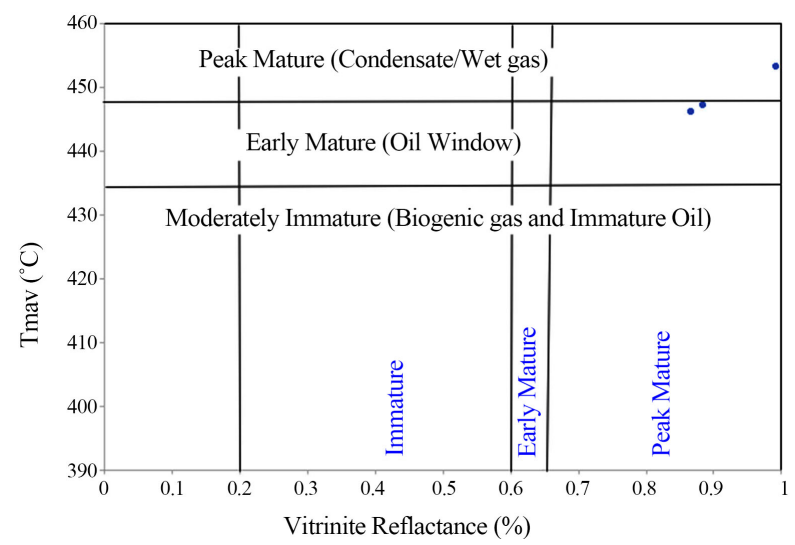

Figure 10. Plot of Tmax versus Vitrinite Reflectance (Ro) showing the maturity levels.

\section{Conclusion}

The shale samples in Calu-2 and Calub-3 well from Bokh Formation have TOC values ranging from 0.31 to $0.87 \mathrm{wt} \%$ (av. $0.59 \mathrm{wt} \%$ ). The TOC values in most of the samples are lower than $0.5 \mathrm{wt} \%$ minimal required for a potential source rock. The kerogen contents of the shales classify as type IV, indicating poor quality organic matter that has no potential to generate hydrocarbons. The thermal maturity parameters based on Rock Eval and vitrinite reflectance data indicate that the shales are within the early to peak mature zone.

\section{Acknowledgements}

This article is supported through the African Union Scholarship scheme, to which we are grateful. We are indebted to all individuals who contributed for the successful accomplishment of this study.

\section{Conflicts of Interest}

The authors declare no conflicts of interest regarding the publication of this paper. 


\section{References}

[1] Barnes, S.U. (1976) Geology and Oil Prospects of Somalia, East Africa. AAPG Bulletin, 66, 389-413.

[2] Getaneh, A. (1988) Potential Hydrocarbon Generating Rock Units Within the Phanerozoic Sequence of the Ogaden Basin, Ethiopia: A Preliminary Assessment Using Lopatin Model. Journal of Petroleum Geology, 11, 461-472. https://doi.org/10.1111/j.1747-5457.1988.tb00832.x

[3] Beauchamp, J., Omer, M.K. and Perriaux, J. (1990) Provenance and Dispersal of Cretaceous Sediments, Ogaden Basin, Ethiopia. Ministry of Mines and Petroleum of Ethiopia, Addis Ababa. (Unpublished Report)

[4] Worku, T. and Astin, T.R. (1992) The Karoo Sediments (Late Palaeozoic to Early Jurassic) of the Ogaden Basin, Ethiopia. Sedimentary Geology, 76, 7-21. https://doi.org/10.1016/0037-0738(92)90136-F

[5] Hunegnaw, A., Sage, L. and Gonnard, R. (1998) Hydrocarbon Potential of the Intracratonic Ogaden Basin, Senate Ethiopia. Journal of Petroleum Geology, 21, 401-425. https://doi.org/10.1111/j.1747-5457.1998.tb00793.x

[6] Kazmin, V. (1972) The Geology of Ethiopia. Unpublished Report, Addis Ababa, Ethiopia.

[7] Purcell, P.G. (1976) The Marda Fault Zone, Ethiopia. Nature, 261, 569-583. https://doi.org/10.1038/261569a0

[8] Purcell, P.G. (1979) The Geology and Petroleum Potential of the Ogaden Basin, Ethiopia. 80.

[9] Beicip, F. (1985) The Petroleum Potential of Ethiopia. Beicip-Franlab Consultants Report for Ministry of Mines and Energy, Ethiopia, Addis Ababa.

[10] Tsegaye, S.G., Nton, M.E., Boboye, O.A. and Ahmed, W. (2018) Geochemical Characteristics and Hydrocarbon Generation Modelling of Early Triassic to Late Cretaceous Formations within Ogaden Basin, Ethiopia. Journal of Petroleum Science and Technology, 8, 58-75.

[11] Hankel, O. (1994) Early Permian to Middle Jurassic Rifting and Sedimentation in East Africa and Madagascar. Geologische Rundschau, 83, 703-710.

https://doi.org/10.1007/BF00251069

[12] Dawit, L.E. (2010) Adigrat Sandstone in Northern and Central Ethiopia: Stratigraphy, Facies, Depositional Environments and Palynology. Technische Universitat, Berlin.

[13] MoME (2005) Joint Ogaden Basin Study Project. Ministry of Mines of Ethiopia, Addis Ababa.

[14] Bosworth, W. (1994) A Model for the Three-Dimensional Evolution of Continental Rift Basins, North-East Africa. Geologische Rundschau, 83, 671-688. https://doi.org/10.1007/BF00251067

[15] Tissot, B.P. and Welt, D.H. (1984) Petroleum Formation and Occurance. Second Edition, Springer, Berlin. https://doi.org/10.1007/978-3-642-87813-8

[16] Waples, D.W. (1985) Geochemistry in Petroleum Exploration. D. Reidel Publishing Company, Dordrecht. https://doi.org/10.1007/978-94-009-5436-6

[17] Landford, F.F. and Blanc-Valleron, M.M. (1990) Interpreting Rock-Eval Pyrolysis Data Using Graphs of Pyrolizable Hydrocarbons vs. Total Organic Carbon. AAPG Bulletin, 74, 799-804. https://doi.org/10.1306/0C9B238F-1710-11D7-8645000102C1865D 
[18] Bordenove, M.L., Espitalie, J., Leplat, P., Oudin, J.L. and Vandenbrouke, M. (1993) Screening Techniques for Source Rock Evaluation. In: Bordenove, M.L., Ed., Applied Petroleum Geochemistry, Editions Technip, Paris, 217-278.

[19] Hunt, J.M. (1996) Petroleum Geochemistry and Geology. Second Edition, W. H. Freeman and Company, New York.

[20] Van Krevelen, D.W. (1950) Graphical-statistical Method for the Study of Structure and Reaction Processes of Hydrocarbons and Coal. Fuel, 29, 228-269.

[21] Waples, D.W. (1991) Recent Developments in Petroleum Geochemistry. Bulletin of the Geological Society of Malaysia, 28, 107-122. https://doi.org/10.7186/bgsm28199106

[22] Soviet Petroleum Exploration Expedition (SPEE) (1993) Report on Geological Structure and Reserves Estimation of the Calub Gas-Condensate Field. Dire Dawa, Ethiopia. Addis Ababa, Ethiopia. 